Journal of Qualitative Criminal Justice \& Criminology

\title{
Book Review | The Insane \\ Chicago Way: The Daring \\ Plan by Chicago Gangs to \\ Create a Spanish Mafia
}

Thomas Barker ${ }^{1}$

${ }^{1}$ Eastern Kentucky University

Published on: Apr 01, 2015

DOI: $10.21428 / 88 \mathrm{de} 04 \mathrm{a} 1.17374606$

License: Creative Commons Attribution 4.0 International License (CC-BY 4.0). 
John M. Hagedorn. The Insane Chicago Way: The Daring Plan by Chicago Gangs to Create a Spanish Mafia. University of Chicago Press, 2015; 300 pp.; ISBN: 9780226232935.

In The Insane Chicago Way, Professor Hagedorn opines that the super street gangs in Chicago have fundamentally changed since the 1990s. He provides an "institutionalized history" of the rise and fall of the Spanish Growth and Development (SGD) alliance to document the fundamental changes in Chicago. He rightly concludes that the SGD is "almost completely unknown to the public, the police, the professors and even most gang members" (p. 1). This powerful SGD case study is supported by the author's long history of gang study and his interviews with gang leaders and street gang members, and with organized crime-Chicago Outfit (Italian Mafia) leaders. His interviews with a retired Outfit leader show the ties between street gangs and organized crime-overlooked by gang researchers who see street gang as "disorganized" crime.

The book examines the networks of power between police corruption, politicians, and street gangs, demonstrating what is known as the "Chicago Way"-envelopes stuffed with money liberally handed to both cops and politicians. These networks of power are often not addressed by street gang experts. Furthermore, Hagedorn addresses the variable nature of gang violence, documenting that Chicago street gangs control violence when they recognize that random violence is bad for business(i.e., random violence interferes with profitable criminal activity) and draws too much attention. His discussion of Chicago street gangs may cause us to reexamine what we think we know about gangs and what we should do about gangs. Reading The Insane Chicago Way did that for this reader. The key to his argument is the formation and maintenance of coalitions or alliances between gangs.

The gang alliances of Chicago and Los Angeles - the United States' street gang capitals - have received a lot of popular and scientific study, but Hagedorn is the first to address Chicago's unique Spanish Growth and Development alliance - why and how it developed and why it crashed and burned. Historically, in both cities gang alliances developed along racial and ethnic lines; however, Chicago's gang alliances took on a multiracial and multicultural character. Los Angeles's Black street gangs formed the Blood and Crips alliances and the LA Latino gangs came together under the Sureno's alliance controlled by the Mexican Mafia prison gang. The animosity between Blacks and the immigrant Latinos shaped the gang alliances in Los Angeles, particularly between incarcerated gang members. Chicago's street gangs, on the other hand, came together under the banner of the People and Folk alliances formed and led by incarcerated Black gang leaders. Unlike in Los Angeles, in Chicago Latino and White gangs joined these alliances, but their membership was predominately African American. According to Hagedorn, the Chicago street gang alliances came into being for three reasons: (a) the need to control random and excessive violence; (b) the need to protect incarcerated members 
and provide for the welfare of leaders; and (c) the desire to engage in crime for profit-organized crime.

Historically, the alliances became necessary because the war on drugs resulted in the mass incarceration of minority gang members in Chicago and other urban U.S. cities. While incarcerated in 1978, Larry Hoover, leader of Chicago's Gangster Disciples (a Black street gang), formed the Folk multiracial alliance in Illinois's Stateville prison to prevent the out-of-control neighborhood gang violence from spilling over into the prisons, then overcrowded by minority gang members. The same year, Jeff Fort of El Rukn (a Black gang), Bobby Gore of the Vice Lords (a Black gang), and Gustavo Colon of the Latin Kings (a Latino gang) formed the People multiracial alliance in response. It was not long before the alliance leaders, recognizing the power of what they had created, were running the street gang crime business, primarily drug trafficking, from their prison cells. Furthermore, the gang leaders demonstrated their ability to control gang violence, even though for all the wrong reasons, proving that gangs are not always "disorganized" crime. The street gang crime business provided income for the incarcerated members and leaders and also controlled violence.

The Chicago Black gangs and their alliances sought to emulate the most successful organized crime coalition in Chicago history-the Chicago Outfit and their Commission. The Outfit "turned over" street level drug sales to the street gangs, but they did not relinquish their traditional protection through the top-down-politicians and police commanders-Chicago Way system [discussed fully below]. The Folk and People alliances did not have access to such protection. Their networks of power and efforts to control illegal drug markets were blunted by the savage war on Black gangs perpetrated by the Chicago Police Department (CPD), exemplified by the torture of more than one hundred Black gang members by CPD Commander Jon Burge. The alliances' efforts to join in the Chicago Way system were further inhibited by the deplorable economic conditions of Blacks. As a result, overt racism precluded Black participation in Chicago politics. Even those few elected Black politicians were beholden to the Daley machine and the distribution of patronage. Failure to control the politicians and the police doomed the street gangs' alliance-building efforts.

One of Hagedorn's contributions to the literature on street gangs is his discussion of "the centrality of police corruption to the persistence of Chicago's gangs" (p. 142). Hagedorn's Outfit informant pointedly states, "Without the cops, none of this stuff could happen." The author's analysis supports this statement.

Chicago's history of police corruption and it support for organized crime is legendary. The author demonstrates that in Chicago police corruption is "strongly related" to the rise of street gangs in the 1960s, and that this relationship has continued and expanded. However, the strategies used by the Outfit and the street gangs were different. Throughout its Chicago history, the Outfit corrupted the police from the top (politicians and police commanders) down. The Chicago Way distributed cash-filled 
envelopes to police commanders and politicians, in return they ensured the smooth operation of crime business. Individual corrupt officers scored on their own, but power and control came from above. As late as 1997, Police Commissioner Matt Rodriguez was forced to resign because of ties to the Outfit. Chicago police officers worked as hit men for the Outfit, similar to the NYPD "Mafia Cops, "Louis Eppolito and Stephen Caracappa, in the 1980s and early 1990s. According to Hagedorn, when Black and Latino street gangs took over the retail drug sales from the Outfit, the nature of police corruption changed because Outfit protection did not extend to street gangs and their drug crime networks. Black and Latino street gangs had to strike protection deals with individual officers and units themselves.

In the 1970s, the Marquette Ten was a group of CPD officers who made their own deals with the Vice Lords-a Black gang in the People alliance - and West Gangs to pay for protection of their drug operation. In the most infamous example, the Latin Folk gangs colluded with a CPD gang specialist, Joseph Miedzianowski-called the most corrupt CPD officer in history. OK Miedzianowski robbed drug dealers and kept their money. He sold confiscated drugs to Latin Folk gangs. He was a major drug supplier to the gangs, even selling them on his own. He made crack deals in the parking lot behind the police station where he worked. Hagedorn rightly concludes that rogue cops such as Miedzianowski represent only $5 \%$ of the Chicago Police Department and other urban police departments waging the war on drugs. However, important to this discussion is the organized efforts of street gangs, and in this case the Latin Folk gangs, to build working relationships with police to further their illicit operations - a factor often ignored in street gang research. Hagedorn says we should include police corruption in our gang research agenda, and I agree.

Further complicating the "safe" operation of crime business - an Outfit characteristic - was that Black gang members as criminal actors failed to provide for the future as was common to the Outfit. The Outfit invested in legitimate businesses and sponsored future doctors, lawyers and politicians while deigning publicity. Planning for the future by ensuring maximum control of the political system and attendant patronage made the Outfit the powerful crime organization it was and still is. Black gang members and their leaders lived for the moment in conspicuous consumption-an unsuccessful way to develop a lasting tradition of power.

The final blow to the People and Folk alliances came when their leaders were sent to more secure federal ultra-maximum prisons, cutting off their ability to communicate with and to direct members on the street and resulting in a return to disorganized crime. For these reasons as well as the traditional animosity between Blacks and Latinos, the multiracial, but predominately Black, People and Folk alliances faded from the scene, making way for the Spanish Growth and Development (SGD) alliance: a coalition of Latino Folk gangs, such as the Insane Dueces, Insane Dragons, Insane Popes, Insane Spanish Cobras, Insane Unknowns, Maniac Latin Disciples, Latin Lovers and Latin Kings. 
Latino gang alliances, formed in the 1970s to fight racist White gangs provided a model for the new Latino alliance. The SGD movement, like the Folk movement, started in Stateville Prison; in 1989 Latin Folk gang leaders called for all Folk gangs to join a Latino alliance - the Spanish Growth and Development alliance. The new proposed alliance had a developed structure, a constitution and bylaws, and membership forms modelled after the Latin King's structure and organization. The primary reasons for forming the new alliance were the same that led to the formation of the now fading multiracial Folk alliance - control violence on the street, protect incarcerated gang members and leaders, and keep the gangs focused on criminal activities. However, the strength of accepting this model evolved into a major weakness. A dispute resolution board, La Tabla, was formed to resolve disputes between members and gangs. Hagedorn opines that the original concept "set forth a daring plan to transform Latino gang life in Chicago into a more rational, violence-mediating, and consciously criminal structure." It just didn't work out that way.

Sixteen Latino Folk gangs formed the SGD. Soon after the formation, networks of power developed within the SGD alliance as the two largest gangs - the Maniac Latin Disciples and the Insane Spanish Cobras-recruited fellow Latino Folk gangs to join their factions, or families. Three families soon developed as the gangs joined forces: The Insane Family - seven gangs led by the Insane Spanish Cobras; The Maniac Family-five gangs led by the Maniac Latin Disciples; and The Almighty Familyfour gangs led by the Simon City Royals (a White gang). The families of gangs, not forgetting their prior disputes over territory and previous violent acts, began to engage in violent power struggles that eclipsed the goal of profits for all and led to disaster: a War of the Families.

The War of the Families degenerated into coordinated attacks by The Maniac Family against The Insane Family on February 13, 1996, and the next day, February 14. The attacks left seven people shot and marked the collapse of the Spanish Growth and Development alliance. They also ushered in a War of the Families that resulted in the deaths of hundreds of Chicago gang members.

Hagedorn's case study, The Insane Chicago Way, is an excellent study of the rise and fall of the Spanish Growth and Development alliance. I must admit that I, and probably most gang researchers, was not aware of the SGD and the desire by Chicago Latino gangs to create a Spanish Mafia using the Chicago Outfit as a model. Hagedorn's work explains why this alliance developed and how it disintegrated. His findings have implications for the general study of gangs and add to our knowledge of how gangs operate in the underground economy and create the necessary networks of power for safe/protected operation of illicit businesses. Gangs are not as disorganized as many opine. This work is a significant contribution to the study of Chicago street gangs and gangs in general and should be read and studied by all serious students of street gangs. 